Pishchukhina O. A.

Ph.D., Associate Professor (Docent), Kharkiv National University of Radio Electronics, Ukraine, E-mail: pishchukhina@gmail.com

\title{
ANALYTICAL SUPPORT OF REQUIREMENTS DEVELOPMENT FOR INTELLIGENT E-LEARNING SYSTEMS
}

The problems of analysis and modeling of requirements while development of e-learning systems with feedback are considered. Subject area of requirements development is determined, choice of CASE-tools for creating models from generated subject area is explained. Visual models of functional requirements and user requirements in the form of diagrams showing the development of behavior and the logical structure of the system are developed. Simulation models explain the events and the corresponding response of the system and can represent its processes of interaction on more higher level of abstraction and allow to reveal incorrect, inconsistent, missing or redundant requirements. Consequence diagram, diagram of cooperation and state transition diagram are considered as analytical support of requirements development for intelligent e-learning systems.

Keywords: analytical support, e-learning, requirements development.

\section{INTRODUCTION}

Information and computer technologies are an integrate part of the present society, especially in the sphere of education including higher education of Ukraine which is under the influence of Bologna Process now. Learning process in a modern university requires using of e-learning tools as a part of independent work of undergraduate and Master students. Creation of intelligent computer systems allowing to master skills and competencies without teacher's involvement is a mainstream of e-learning development and enhancement [1].

E-learning system must perform not only function related to providing the theoretical material, but also controls function of learning, testing, solving tasks and students estimation with searching of «blind» spots in their answers and providing recommendations for returning to the part of theoretical material, which has caused difficulties, or for additional training in testing part. In addition, the recommendations should contain information about errors appearing, ways of their eliminating and about the level of knowledge. So, the distinctive feature of intelligent e-learning is a presence of electronic feedback to students that can improve mastering of material studied. Electronic feedback is maintained by special interactive modules which are responsible for estimation of student answers and diagnosis of place and type of errors made (often poorly formalized) [2,3].

The analysis of existing e-learning computer systems shows that they are mostly presented as testing and information systems without any kind of learning process feedback, so they can not be consider as the intelligent ones. One of the great disadvantage of such systems is that they can not be used throughout the whole cycle of learning process and limited by certain set of primitive functions (such as e-books, educational databases, etc.). Thus, the practical importance and actuality of given problem is proved by necessity of elaboration computer systems with electronic feedback that would make learning process more effective and convenient for self-development of persons trained [4].

\section{PROBLEM STATEMENT}

The problem of intelligent computer systems elaboration is considered as a creation of complex computer projects and associated closely with the development of requirements for their structure, functions and software content. Requirements describe behavior of the system, the properties of the system, its classes and attributes and restrict the process of a computer system developing [5].

Analysis and modeling of requirement demand special formalized approaches which could consider interests of all persons involved in e-learning process: students with different psycho-types, levels of basic knowledge, speed of processing and perception of information and teachers with theirs experience «how to do», «how to teach», «how to estimate» and «how to determine a genuine reason of a mistake made». Moreover other external facts such as norms of curriculums, learning catalogues, etc. should be taken into account also.

Investigation of given poor formalized subject area proves that elaboration of complex computer system is impossible without analytical support of requirements development. Analytical support of process of requirements development for intelligent e-learning system must contain formalized view of its functions, states and transitions, logical aspects of actions sequence and collaboration between its elements in the form of adequate visual models of functional and user requirements.

\section{PROBLEM SOLVING}

User requirements describe goals and tasks which elearning system allows to solve and indicate what a person trained can do with the system. The ways of presenting this kind of requirements are options of scenarios usage and approach «event-response» [5]. Functional requirements determine software functionality that developers need to build and users would be able to perform. To cover all requirements it is necessary to develop models which display them on a certain level of abstraction and allow to reveal

(C) Pishchukhina O. A., 2013 
incorrect, inconsistent, missing or redundant requirements. Data flow diagrams, state transition diagrams, sequence and collaborations diagrams are referred to such conceptual representation of given intelligent computer system. Each model describes a specific aspect of the system, uses a set of diagrams or formal descriptions and documents of specified format and also reflects the point of view and is the subject of a variety of people with specific interests, roles or tasks. These models provide a useful tool for analyzing problems, software design and exchange of information between modules developed. Simulation enhances the functional and users requirements coverage and handling and improves the quality of the system [6].

The most effective way of visual models creating is using the special standard language of object-oriented modeling Unified Modeling Language (UML) [7]. At the level of abstractions diffraction, which is suitable for the analysis of requirements, UML-notation is used for all types of intelligent e-learning system diagrams. Analysis modeling techniques are under supports of a variety of business automation tools and software design known as computeraided software engineering (CASE) [8]. This choice is due to the next advantages over conventional means of drawing: 1) they easily allow to improve the quality of the diagrams in repeated requirements (since, one can not create an excellent model with the first time and there are some external and internal changes during simulation process, thus, iteration can be a key to success in simulation of systems ); 2) CASE- tools support the rules for each modeling method and can identify syntax errors, inconsistencies and detect semantic errors in the chart that is not always possible to do manually.

On fig. 1 and fig. 2 sequence diagram and diagram of collaboration which show transactions between separate modules of intelligent e-learning system are presented.

They reflect how systems modules exchange data in dynamics and shows interactions of classes and messages exchanged for better understanding user requirements. Part of state transition diagram (acceptance of person's answer and comparing with the right one) is presented on fig. 3 and forms complete and clear understanding of the mechanism of a final number of states.

State transition diagram contains three types of elements: initial, final states and state transitions. The diagram shows the state transition as not a part of processes performed by the system, but the only possible state changes, resulting from these processes. Transition diagram helps to understand the intended behavior of system and checking whether all the necessary states and state transitions are described correctly and fully in the functional requirements.

\section{CONCLUSION}

Simulation models of user and functional requirements were elaborated on the basis of CASE-tools and provide an analytical support explaining the events and the corresponding responses of the system. It represents process of modules interaction on more higher level of

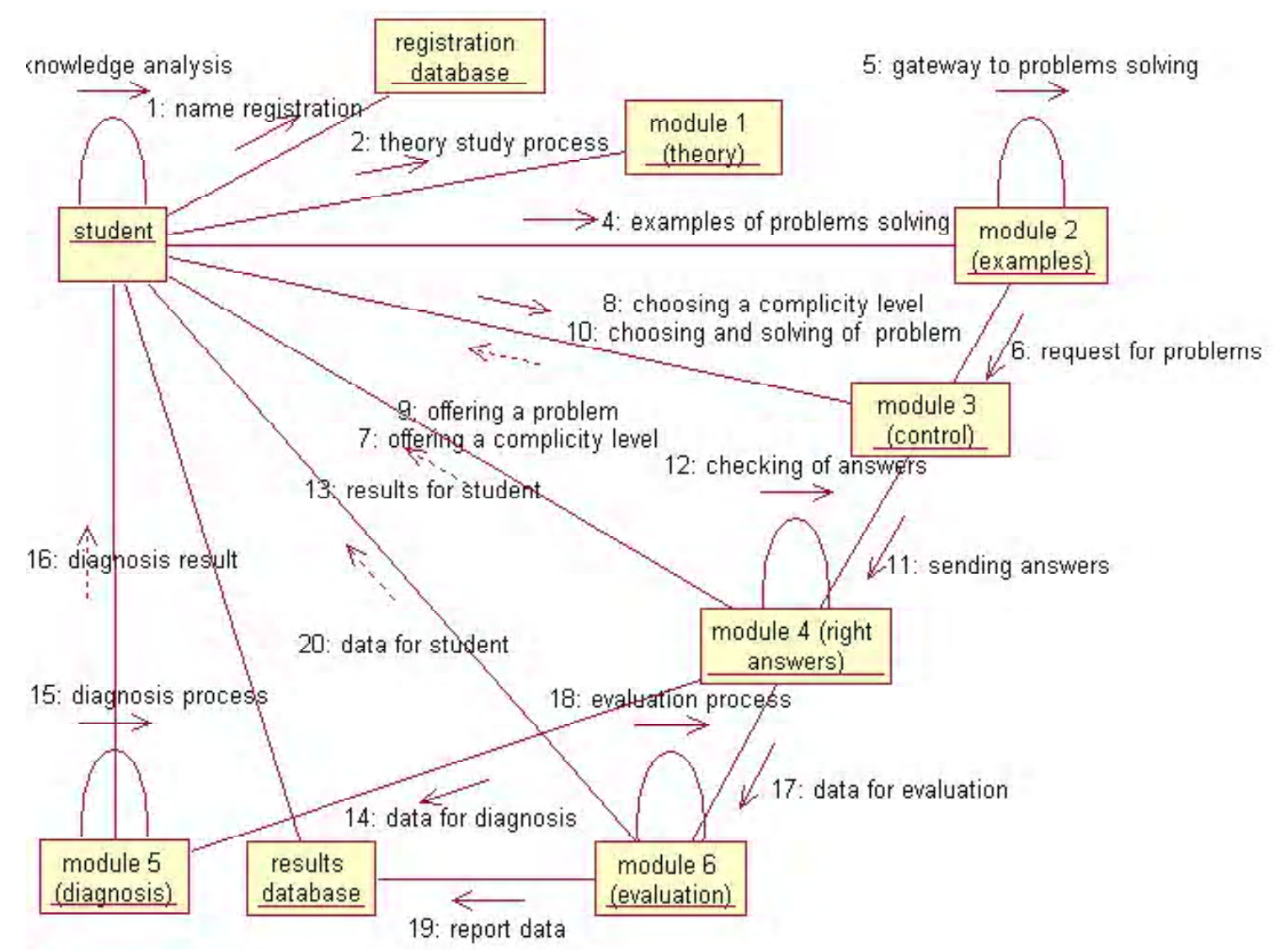

Fig. 1. Intelligent e-learning system collaboration diagram 


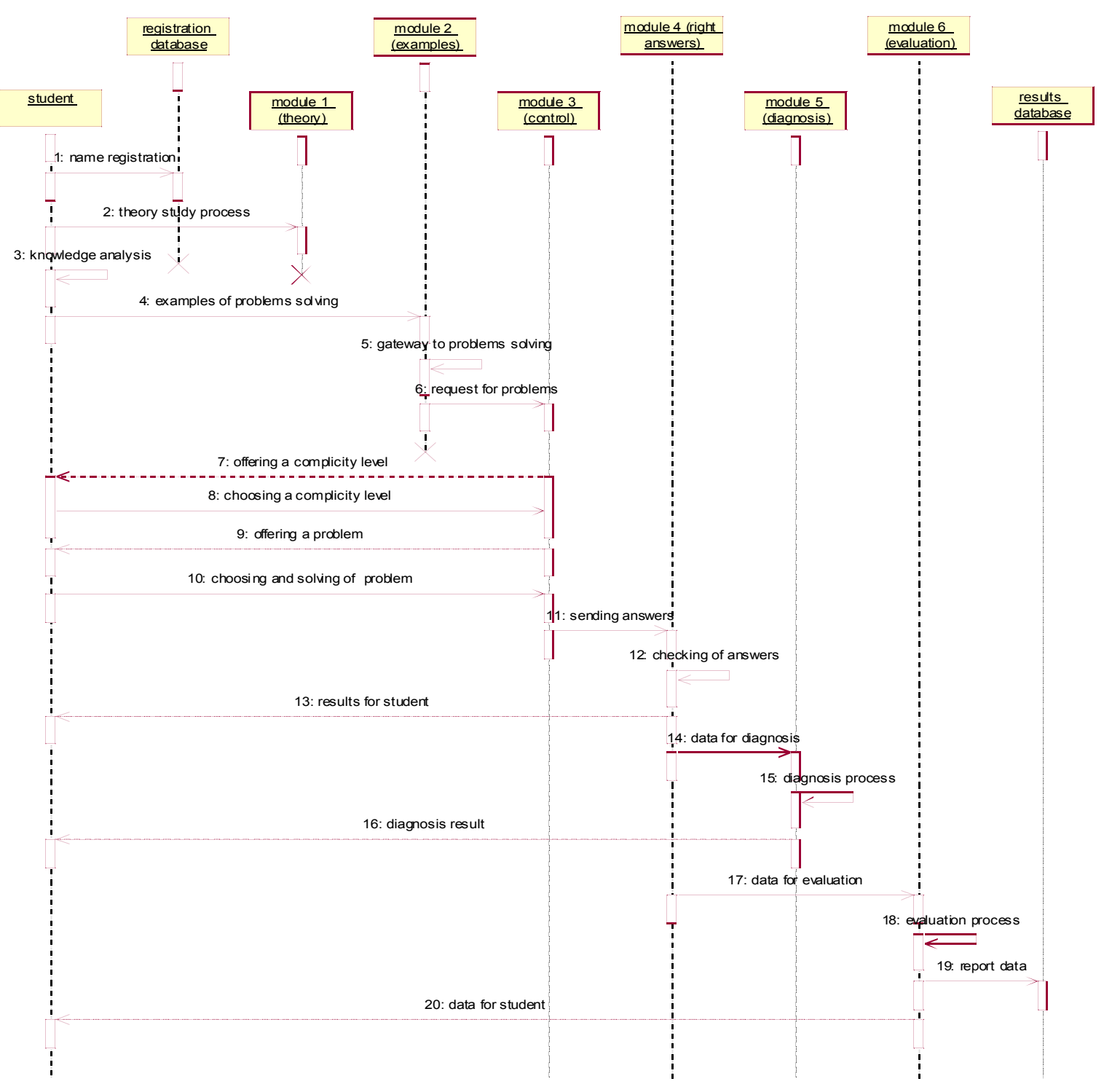

Fig. 2. Intelligent e-learning system sequence diagram

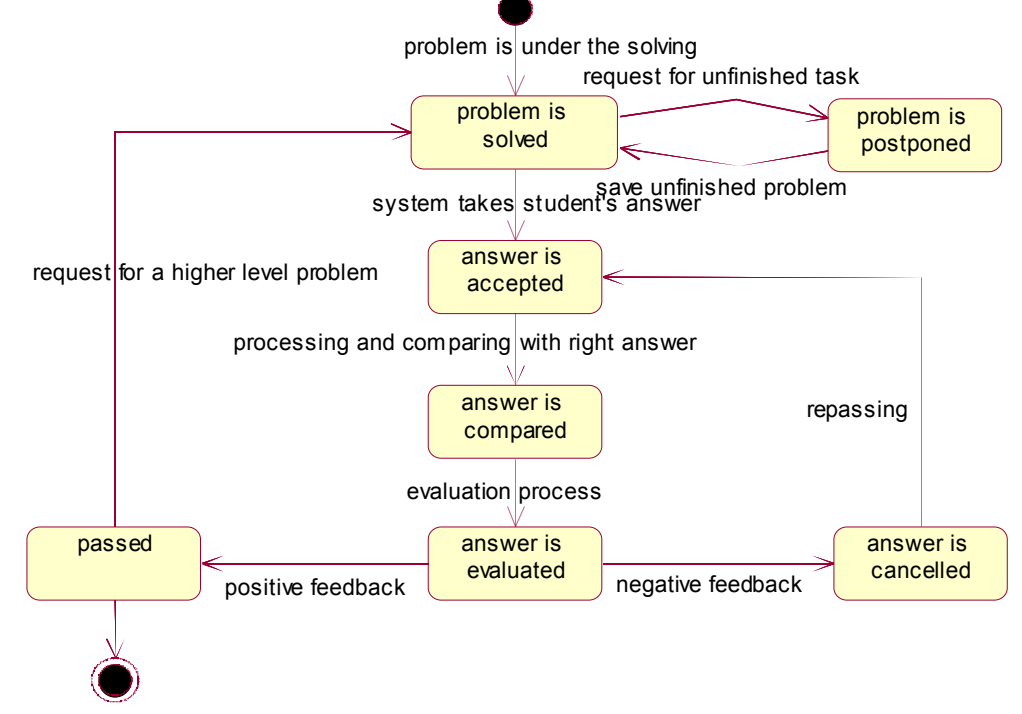

Fig. 3. Part of intelligent e-learning system state transition diagram 
understanding than the one that gives the text specification requirements. However, they could not replace the specification requirements on natural language at all because each simulation received has its advantages and its limitations. Visual modeling of intelligent e-learning system is a way of problems perception with visible abstractions, concepts and reproducing of real-world objects. Modeling is carried out through UML-language which includes specified graphical elements of the model and notations. Presented models are various diagrams associated with each other and with their common data definitions in the data dictionary that allows to maintain the model in a consistent state and in accordance with the functional and users requirements for software content.

\section{SPISOK LITERATURY}

1. Пищухина, О. А. Интеллектуальные обучающие системы в сфере технического образования / О. А. Пищухина // Bсеукраїнська науково-технічна конференція «Інтегровані комп’ютерні технології в машинобудуванні: ІКТМ-2010». Харків : Нац. аерокосм. ун-тет. - 2010. - Т. 2. - С. 118.

2. Пищухина, О. А. Подход к формированию обратной связи в интеллектуальных обучающих системах в сфере выс- шего технического образования / О. А. Пищухина, А. Ю. Клочок // Радіоелектроніка, інформатика, управління. - 2011. - № 2(25). - С. 107-110.

3. Pishchukhina, O. A. Algorithm of computer learning programs with feedback development / O. A. Pishchukhina, A. Yu. Klochok // Всеукраїнська науково-технічна конференція «Інтегровані комп'ютерні технології в машинобудуванні : ІКТМ-2011». - Х. : Нац. аерокосм. ун-тет. 2011. - T. 2 - C. 123.

4. Кулик, А. С. Модели и алгоритмы поиска ошибок при решении задач с использованием компьютерных средств обучения. / А. С. Кулик, О. А. Пищухина, А. Ю. Клочок // Радіоелектроніка, інформатика, управління. - 2012. № 1(26). - C. 59-63.

5. Вигерс, $K$. Разработка требований к программному обеспечению : пер. с англ. / К. Вигерс. - М. : Издательскоторговый дом «Русская редакция», 2004. - 576 с.

6. Рамбо, Дж. UML 2.0. Объектно-ориентированное моделирование и разработка. 2-е изд.: Пер. с англ. / Дж. Рамбо, М. Блаха. - С.Пб. : Питер, 2007. - 544 с.

7. Буч, Г. Язык UML. Руководство пользователя : пер. с англ. / Г. Буч, Д. Рамбо, А. Джекобсон. - М. : ДМК, 2001.- 432 с.

8. Боггс, У. UML и Rational Rose 2002: Пер. с англ. / У. Боггс, М. Боггс. - М. : ЛОРИ, 2004. - 580 с.

Стаття надійшла до редакції 28.10.2013.

Пищухина О. А.

Канд. техн. наук, доцент, Харьковский Национальный университет радиоэлектроники, Украина

АНАЛИТИЧЕСКАЯ ПОДДЕРЖКА РАЗРАБОТКИ ТРЕБОВАНИЙ ДЛЯ ИНТЕЛЛЕКТУАЛЬНЫХ КОМПЬЮТЕРНЫХ СИСТЕМ ОБУЧЕНИЯ

Рассмотрены вопросы анализа и моделирования требований при разработке средств электронного обучения с обратной связью. Определена предметная область формирования требований, обоснован выбор CASE-средств для построения моделей сформированной предметной области. Разработаны визуальные модели функциональных требований и требований пользователя в виде диаграмм, отражающих динамику поведения и логическую структуру системы. Приведенные диаграммы представляют собой инструментальное средство аналитической поддержки процесса формирования требований к интеллектуальным компьютерным системам обучения.

Ключевые слова: аналитическая поддержка, электронное обучение, разработка требований.

Піщухіна О. О.

Канд. техн. наук, доцент, Харьківський Національний університет радіоелектроніки, Україна

АНАЛІТИЧНА ПІДТРИМКА РОЗРОБКИ ВИМОГ ДЛЯ ІНТЕЛЕКТУАЛЬНИХ КОМП'ЮТЕРНИХ СИСТЕМ, ЩО НАВЧАЮТЬ

Розглянуто питання аналізу та моделювання вимог при розробці засобів електронного навчання зі зворотним зв'язком. Визначено предметну область формування вимог, обгрунтовано вибір CASE-засобів для побудови моделей сформованої предметної області. Розроблено візуальні моделі функціональних вимог і вимог користувача у вигляді діаграм, що відображають динаміку поведінки і логічну структуру системи . Наведені діаграми $є$ інструментальним засобом аналітичної підтримки процесу формування вимог до інтелектуальних комп'ютерних систем навчання.

Ключові слова: аналітична підтримка, електронне навчання, розробка вимог.

\section{REFERENCES}

1. Pishhuhina O. A. Intellektual'nye obuchajushhie sistemy v sfere tehnicheskogo obrazovanija, Vseukraïns'ka naukovotehnichna konferencija «Integrovani komp'juterni tehnologii v mashinobuduvanni: IKTM-2010», Harkiv, Nac. aerokosm. un-tet., 2010,Vol. 2, p. 118.

2. Pishhuhina O. A., Klochok A. Ju. Podhod k formirovaniju obratnoj svjazi v intellektual'nyh obuchajushhih sistemah v sfere vysshego tehnicheskogo obrazovanija, Radio Electronics, Computer Science, Control, 2011, No. 2, pp. 107-110.

3. Pishchukhina O. A., Klochok A. Yu. Algorithm of computer learning programs with feedback development, Vseukraïns'ka naukovo-tehnichna konferencija «Integrovani komp'juterni tehnologiï v mashinobuduvanni: IKTM-2011», Harkiv: Nac. aerokosm. un-tet, 2011, Vol. 2, pp. 123.

4. Kulik A. S., Pishhuhina O. A., Klochok A. Ju. Modeli i algoritmy poiska oshibok pri reshenii zadach s ispol'zovaniem komp'juternyh sredstv obuchenija, Radio Electronics, Computer Science, Control, 2012, No. 1, pp. 94-98.

5. Vigers K. Razrabotka trebovanij k programmnomu obespecheniju.: per. s angl., Moscow, Izdatel'sko-torgovyj dom «Russkaja redakcija», 2004, 576 p.

6. Rambo Dzh., Blaha M. UML 2.0. Ob'ektno-orientirovannoe modelirovanie i razrabotka. 2-e izd.: per. s angl. SanktPeterburg, Piter, 2007, 544 p.

7. Buch G., Rambo D., Dzhekobson A., Jazyk UML. Rukovodstvo pol'zovatelja, per. s angl., Moscow, DMK, 2001, 432 p.

8. Boggs U., Boggs M. UML i Rational Rose 2002: per. s angl,, Moscow, LORI, 2004, 580 p. 